This item was submitted to Loughborough's Research Repository by the author.

Items in Figshare are protected by copyright, with all rights reserved, unless otherwise indicated.

\title{
Pathways of high-latitude dust in the North Atlantic
}

PLEASE CITE THE PUBLISHED VERSION

http://dx.doi.org/10.1016/j.epsl.2016.11.034

\section{PUBLISHER}

(c) Elsevier

\section{VERSION}

AM (Accepted Manuscript)

\section{PUBLISHER STATEMENT}

This work is made available according to the conditions of the Creative Commons Attribution-NonCommercialNoDerivatives 4.0 International (CC BY-NC-ND 4.0) licence. Full details of this licence are available at: https://creativecommons.org/licenses/by-nc-nd/4.0/

\section{LICENCE}

CC BY-NC-ND 4.0

\section{REPOSITORY RECORD}

Baddock, Matthew, Thomas Mockford, Joanna Bullard, and Throstur Thorsteinsson. 2016. "Pathways of Highlatitude Dust in the North Atlantic". Loughborough University. https://hdl.handle.net/2134/23441. 
1 Pathways of high-latitude dust in the North Atlantic

2

3 Matthew C. Baddock $^{a}$, Tom Mockford ${ }^{a}$, Joanna E. Bullard ${ }^{a}$ and Throstur

4 Thorsteinsson $^{\mathrm{b}}$

5

6 aDepartment of Geography, Loughborough University, Loughborough, UK

7 LE11 3TU

$8 \quad$ m.c.baddock@lboro.ac.uk; t.mockford@lboro.ac.uk; j.e.bullard@lboro.ac.uk

9

$10{ }^{b}$ Environment and Natural Resources \& Institute of Earth Sciences, University

11 of Iceland, Askja, Sturlugata 7, 101 Reykjavik, Iceland

12 ThrosturTh@hi.is

13

14

15

16 Corresponding author:

17 Matthew Baddock (m.c.baddock@lboro.ac.uk)

18

19

20

21

22

23

24

25

26

27 
The contribution of mineral dust from high-latitude sources has remained an under-examined feature of the global dust cycle. Dust events originating at high latitudes can provide inputs of aeolian sediment to regions lying well outside the subtropical dust belt. Constraining the seasonal variability and preferential pathways of dust from high-latitude sources is important for understanding the potential impacts that the dust may have on wider environmental systems, such as nearby marine or cryospheric domains. This study quantifies dust pathways from two areas exhibiting different emission dynamics in the north and south of Iceland, which is a prominent Northern Hemisphere dust source. The analysis uses air parcel trajectory modelling, and for the first time for high-latitude sources, explicitly links all trajectory simulations to time-specific (meteorological) observations of suspended dust. This approach maximises the potential for trajectories to represent dust, and illustrates that trajectory climatologies not limited to dust can grossly overestimate the potential for dust transport.

Preferential pathways emerge that demonstrate the role of Iceland in supplying dust to the Northern Atlantic and sub-Arctic oceans. For dust emitted from northern sources, a dominant route exists to the northeast, into the Norwegian, Greenland and Barents Seas, although there is also potential for delivery to the North Atlantic in summer months. From the southern sources, the primary pathway extends into the North Atlantic, with a high

51 density of trajectories extending as far south as $50^{\circ} \mathrm{N}$, particularly in spring and summer. Common to both southern and northern sources is a pathway to 
53 the west-southwest of Iceland into the Denmark Strait and towards

54 Greenland. For trajectories simulated at $\leq 500 \mathrm{~m}$, the vertical development of

55 dust plumes from Iceland is limited, likely due to the stable air masses of the

56 region suppressing the potential for vertical motion. Trajectories rarely ascend

57 high enough to reach the central portions of the Greenland Ice Sheet. The

58 overall distribution of trajectories suggests that contributions of Icelandic dust

59 are relatively more important for neighbouring marine environments than the

60 cryosphere.

61 Keywords; Iceland, Greenland, aerosols, Arctic, HYSPLIT

\section{Introduction}

65

66

67

Recent research has cast light on the sources and potential impacts of dust that originates from the global high-latitudes (Bullard et al., 2016). Although considerably smaller in area compared to sub-tropical dust source regions, dust emissions at high-latitudes can be intense (Arnalds, 2010; Bullard, 2013). Many high-latitude, cold climate environments are characterised by winds which regularly exceed the threshold for aeolian entrainment, as well as surfaces with large volumes of fine sediment and little vegetation cover (Bullard, 2013). When combined, these factors promote dust emission into the atmosphere. The main high-latitude dust source regions, defined as $\geq 50^{\circ} \mathrm{N}$ and $\geq 40^{\circ} \mathrm{S}$, are Alaska, Canada, Greenland, Iceland, Antarctica, New Zealand and Patagonia (Bullard et al., 2016). Dust storms originating from these areas can cause erosional degradation of soils (Gísladóttir et al., 2010) 
and are recognised to have a potential impact on air quality (Polissar et al., 1998; Thorsteinsson et al., 2011). Deposition of aeolian transported sediment in such environments can also contribute to local soil development and may have regional and global impacts as material is transferred from the terrestrial to the marine and cryospheric systems (Atkins and Dunbar, 2009; Arnalds et al., 2014). Part of the significance of high-latitude dust sources is that they are found away from the major low latitude global dust belt and are therefore regionally important contributors of aeolian sediment input (Gassó and Stein, 2007; Gassó et al., 2010; Bhattachan et al., 2015; Neff and Bertler, 2015). For example, high-latitude dust storms can input large quantities of sediments to the polar oceans impacting ocean floor sediment accumulation rates (Chewings et al., 2014). These sediments may also be iron-rich (Schroth et al., 2009) and have the potential to contribute to iron fertilization of the oceans (Nielsdottir et al., 2009; Arnalds et al., 2014). Crusius et al. (2011) suggested that a single dust storm from the Copper River valley, Alaska contributed 30200 tons of soluble iron to the iron-limited sub-Arctic north Pacific Ocean.

An increasing body of research has identified seasonal patterns in highlatitude dust emissions at source (recently reviewed by Bullard et al. 2016), but little attention has been paid to the pathways along which the dust is transported. With the notable exception of Patagonia (Gassó and Stein, 2007; Gassó et al., 2010), dust transport pathways from high-latitudes are often omitted from global maps that summarise dust activity and its transport routes (Middleton et al., 1986; Muhs et al., 2014). Commonly based on air trajectory modelling, there has been considerable work into the identification of long 
term (i.e., multi-year rather than event-based) dust transport patterns from subtropical sources (e.g., McGowan and Clark, 2008; Bhattachan et al., 2012), with far fewer investigations addressing transport from the highlatitudes. High-latitude transport pathways that have been investigated include

106 those from sources in the Dry Valleys of Antarctica (Bhattachan et al., 2015), 107 and from indicative sources in Patagonia and New Zealand (Neff and Bertler, 108 2015). An important limitation of many contemporary 'dust' transport 109 climatologies that have been produced for both low latitude and high-latitude 110 regions is that they are typically constrained spatially, but not temporally. In

111 other words, trajectories are generated from known dust sources but often for 112 every day of the year rather than being limited only to those seasons or days 113 when dust was actually present in the atmosphere.

115 The work presented here provides the first long-term, systematic analysis of 116 high-latitude dust pathways that are explicitly associated with dust 117 observations, rather than through a climatology of potential dust transport. 118 Iceland is chosen as a prominent high-latitude dust region, and the aim of this 119 paper is to quantify and understand the impact of source location on dust 120 transport pathways, the variability of pathways as driven by seasonality, and 121 the vertical characteristics of air parcel trajectories associated with dust 122 pathways. Spatially, the study provides insights into which marine areas are 123 most likely to receive aeolian inputs from Iceland, and when, and to what 124 extent there is the potential for the dust to regionally impact the cryosphere. 


\section{Background}

127 Wind erosion in Iceland is common and the country is recognised as one of

128 Earth's most prominent high-latitude dust sources (Arnalds et al., 2001; 2010;

129 Prospero et al., 2012; Bullard et al., 2016). Surface sediments that are

130 susceptible to aeolian processes cover approximately $20,000 \mathrm{~km}^{2}$ (Arnalds et

131 al., 2001; Arnalds, 2010), and their location is closely coupled to that of the

132 volcanic-glacial system (Arnalds et al., 2016) (Figure 1). It has been

133 hypothesised that this area may expand under scenarios of glacial retreat

134 (Cannone et al., 2008) exposing more sediments to potential wind erosion

135 and so increasing the magnitude and frequency of future dust storms

136 (Thorsteinsson et al., 2011; Bullard, 2013).

137 >>Figure $1<<$

138 The most significant dust source regions include north of Vatnajökull

139 (Dagsson-Waldhauserova et al., 2013; 2014) and the southern coast

140 (Thorsteinsson et al., 2011; Prospero et al., 2012), where there are

141 contrasting seasonal patterns of dust emission. In the north, persistent snow

142 cover often restricts dust storms to only the summer months. In the south,

143 dust emissions occur year round, but are less common in summer due to

144 lighter winds and are closely coupled to seasonally-variable sediment supply

145 from the glacio-fluvial system (Old et al. 2005; Prospero et al., 2012;

146 Dagsson-Waldhauserova et al., 2014; Bullard et al., 2016). This system

147 distributes fine sediments across glacial outwash floodplains known locally as

148 sandar. Glacial outburst floods of high magnitude and low frequency (known

149 as jökullhaups) can episodically deliver large amounts of sediment and have 
been linked to periods of increased dust storm frequency (Prospero et al.,

151 2012).

152

153 For the monitoring of regional dust activity, Iceland has an excellent coverage

154 of meteorological stations. Many of these report long-term averages of wind

155 speed and dust-related weather observation codes. Dagsson-Waldhauserova

156 et al. (2014) calculated that Iceland experiences approximately 34 dust days

157 per year, based on a dust day defined as one station recording at least one

158 dust observation. This figure is significantly increased if dust hazes and/or the

159 re-suspension of volcanic ash are included. The impact of wind erosion in

160 Iceland is significant, with dust storms being responsible for approximately $1 / 3$

161 of all air quality exceedances $\left(>50 \mu \mathrm{g} / \mathrm{m}^{3}, 1 \mathrm{~h}\right.$ average) in the greater

162 Reykjavik area, where over $62 \%$ of the total population reside (Thorsteinsson

163 et al., 2011).

165 There have been few studies of the transport of dust from Iceland despite the

166 fact that the surrounding oceans have been identified as a region where

167 phytoplankton are possibly responsive to iron inputs (Nielsdóttir et al., 2009).

168 Arnalds et al. (2014) used a variety of assumptions to estimate dust budgets

169 and deposition rates on land and into oceans to the northeast and south of the

170 island. They estimated that the contribution of dust to the North Atlantic from

171 Icelandic sources might be up to $7 \%$ of the quantity supplied to the same

172 location from North African sources. In terms of longer-distance transport,

173 Dagsson-Waldhauserova et al. (2013) have suggested that Icelandic dust 
may reach Greenland. They highlighted that two periods of elevated dust and one of its relative absence in Greenland Summit ice cores analysed by Donarummo et al. (2002) could be correlated with a 40-year meteorologybased record of dust from northeast Iceland. In finding some particles described as glassy in texture, which they associated with volcanics, Drab et al. (2002) also proposed a potential route for aerosols from Iceland to Greenland. Real-time aerosol mass spectrometry observations of Icelandic dust reaching Ireland have also suggested that Iceland could provide a regional source of aerosol over the North Atlantic (Ovadnevaite et al., 2009). In their recent review article, however, Arnalds et al. (2016) stress that investigations of long range dust transport from Iceland have relied on case studies and are as yet lacking systematic analysis.

\section{Methods}

Dust transport from Iceland was analysed using forward air parcel modelling through the Hybrid Single-Particle Lagrangian Integrated Trajectory (HYSPLIT) tool (version 4) (Draxler and Hess, 1997; 1998). From a specified location, height and time, HYSPLIT computes the position of an air parcel as driven by three-dimensional winds at hourly time steps for a user-determined duration. HYSPLIT, developed by the Air Resources Laboratory of the National Oceanic and Atmospheric Administration, is a widely-used air parcel trajectory model and its developers have recently reviewed the developmental history and use of the model by the atmospheric science community, including examples of its successful application in numerous studies of mineral dust transport (see Stein et al., 2015). While HYSPLIT can be used in a full 
dispersion mode, this analysis of dust pathways from Iceland was based on

200 frequency and distribution of HYSPLIT derived trajectories.

202 HYSPLIT has previously been used to investigate possible pathways from

203 dust sources over multi-year time periods. Where dust transport is the focus,

204 researchers have ensured that trajectories are started from known dust

205 sources, but if no account is taken of when these sources are active then

206 there is a risk that air parcel pathways that do not contain dust are included in

207 the analysis. Long term climatologies of all trajectories from emission sources

208 therefore only demonstrate potential pathways of dust (e.g., McGowan \&

209 Clark, 2008; Bhattachan et al., 2012; Bhattachan et al., 2015). In the current

210 study, we produce a long term transport climatology that is more

211 representative of actual dust transport by only analysing air trajectories

212 related to days and times of dust observation made near Icelandic dust

213 sources. The dust records of two Icelandic meteorological stations at

214 Grímsstaðir and Vatnsskarðshólar were used (Figure 1). These stations were

215 selected for two reasons. First, they have been identified as key indicator

216 stations of dust activity in the north and south of Iceland respectively (e.g.,

217 Dagsson-Waldhauserova et al., 2013; 2014) (Figure 1). Second, a long term

218 record exists over a period common to both locations, allowing all dust

219 observations between 1992-2012 to be considered. According to the multi-

220 decadal analysis of Icelandic dust observations by Dagsson-Waldhauserova

221 et al. (2013), this 20 year period provides an adequate dataset of trajectories

222 from which to derive principal dust pathways (Table 1).

223 > $>$ Table $1<<$ 
224 To compare the results of a full climatology with one restricted to dust

225 observations, firstly, HYSPLIT input control files were batch generated for

226 every day of the study period at a start time of 1200 UTC (7305 trajectories for

227 each site). For analysis of dust-associated pathways (i.e. those constrained to

228 days of dust observation), trajectories were also generated for only those

229 days when a dust-related SYNOP code 06 ('widespread dust in suspension

230 away from the station') were reported. In the Icelandic aeolian setting, some

231 of these dust events involve the entrainment and re-suspension of volcanic

232 material that had previously been deposited at the surface (Thorsteinsson et

233 al., 2012; Bullard et al., 2016). For these runs, trajectories were originated at

234 the station site and at the specific time that the dust code was reported. This

235 time was the first dust observation if several dust events occurred at several

236 times on a given day. By running forward trajectories for known dust days,

237 from locations and times where dust was observed, our analysis is based on

238 trajectories that are explicitly associated with known instances of dust

239 suspension.

241 An important consideration in using dust records from meteorological stations

242 is that the presence of a dust weather code report indicates dust at the

243 reporting station, not that the location is necessarily the source of the dust

244 (O’Loingsigh et al., 2010). In this study however, Grímsstaðir and

245 Vatnsskarðshólar are stations closely associated with Icelandic dust source

246 areas as identified by Arnalds (2010), Arnalds et al. (2014) and Dagsson-

247 Waldhauserova et al. (2013) (Figure 1), so these stations can be taken to

248 represent the activity of source areas. The specific relationships between the 
249 location of these two stations and the principal sources of Icelandic dust

250 emission are discussed later.

252 The meteorological input to drive the HYSPLIT simulations was the monthly 253 NCEP/NCAR global reanalysis product, a commonly used dataset with $2.5^{\circ}$ 254 spatial resolution and described in detail by Kalnay et al. (1996) (see also 255 Harris et al., 2005; Stein et al., 2015). Based on input data, HYSPLIT 256 generates a modelled position for an air parcel and therefore trajectory points 257 on an hourly basis. The method for calculation of vertical motion employed in 258 the model was a 3D vertical wind field derived from the reanalysis data. In 259 producing their climatology of potential dust transport in Australia, McGowan 260 and Clark (2008) ran trajectories for 8 days, arguing that fine dust can remain 261 suspended for that length of time. In our study we compute trajectories for a 262 three day (72 hour) period. While the maximum possible extent of dust 263 transport from Iceland might not be covered over this timescale (Neff and 264 Bertler, 2015), HYSPLIT trajectory accuracy decreases at longer periods 265 (Stohl, 1998), and a shorter timescale increases confidence that the simulated 266 trajectories will represent dust in transport, because (dry and wet) depositional

267 fall-out also increases with time. For this trajectory analysis, a decay 268 parameter for dust in suspension was not considered. The fate of suspended 269 dust at a relatively low level height was evaluated by one set of HYSPLIT 270 simulations run with air parcel start height at $100 \mathrm{~m}$ above ground level 271 (a.g.I.), and also at greater altitude by another group of trajectories starting at $272500 \mathrm{~m}$. The start height for HYSPLIT trajectories varies considerably 273 throughout the literature, and is typically determined by specifics of the 
274 research and study location. Neff and Bertler (2015) for instance recently

275 presented a major climatology of southern hemisphere dust source trajectory

276 analysis based on a 100 m start height for HYSPLIT, while McGowan and

277 Clark (2008) used a 500 m start height for their study of Australian transport

278 pathways. We select two relatively low heights because the focus of this study

279 is not an estimation of the longest potential range for dust transport from

280 Iceland, but to maximise certainty that modelled trajectories do represent the

281 transport of dust entrained from a particular source area. In a unique

282 meteorological experiment overflight which also captured an Icelandic dust

283 event, Blechschmidt et al. (2012) reported the visibility reduction due to dust

284 was more pronounced at observations made below $700 \mathrm{~m}$. These

285 observations provide some support that our simulation run heights of $100 \mathrm{~m}$

286 and $500 \mathrm{~m}$ are well within the dust layer.

288 Summary analysis of the trajectory points from the HYSPLIT model output, 289 including their organisation into seasonal periods, was performed in ArcGIS.

290 Maps of trajectory frequency density are displayed in two ways. The trajectory

291 model produces hourly iteration points in space, and where analysis permitted

292 points to be joined, trajectories were treated as a complete line, so frequency

293 was expressed as the percentage of lines passing through $1 \times 1^{\circ}$ cells on a

294 regular latitude-longitude grid. Using the same grid, the variation of

295 trajectories by altitude was quantified as the percentage of points occurring at 296 different heights. 
298 To assist in the interpretation of near-surface wind fields, dust transport, and

299 the key relationship between emission source areas and the meteorological

300 observation stations, indicative wind roses were generated for Grímsstaðir

301 and Vatnsskarðshólar. These roses were based on mean windspeed from

302 three hourly measurements using data from the Icelandic Meteorological

303 Service for every day of the 20 year study period.

\section{Results}

306 Figure 2 presents a comparison of trajectory frequency distribution between a

307 full climatology, run on a daily basis regardless of whether or not dust was

308 observed at the source, and the trajectory distribution restricted to dust-

309 associated days only. The full climatologies for the two stations appear as

310 approximately concentric rings of trajectory density decreasing away from

311 Iceland, with slight biases in the peak densities extending north and south

312 from Grímsstaðir and Vatnsskarðshólar respectively (Figure 2A and 2C).

$313>>$ Figure $2<<$

314 The distribution of the trajectories associated explicitly with dust observations

315 at each station (Figure 2B and D) reveals an appreciably different pattern

316 compared with the full climatologies. The spatial extent of trajectory density is

317 considerably reduced, and reveals potential preferential pathways for dust

318 transport. From Grímsstaðir, a zone of relatively high trajectory densities can

319 be seen to extend to the north and northeast of Iceland, reaching just beyond

$32070^{\circ} \mathrm{N}$ into the Norwegian and Greenland Seas. In total, over a quarter $(28.1 \%)$

321 of trajectory points occurred north of $70^{\circ} \mathrm{N}$. A less prominent but distinct 
pathway from Grímsstaðir is also detected to the west of Iceland, toward the

323 Greenland coast and into the Denmark Strait. From the southern station of

324 Vatnsskarðshólar, two broad corridors of more dense trajectories are

325 apparent into the North Atlantic, including a predominantly southerly one

326 extending to around $54^{\circ} \mathrm{N}$, and another more southwesterly pathway, the

327 latter somewhat similar to that seen for Grímsstaðir. Only $2.4 \%$ of

328 Vatnsskarðshólar trajectory points were found north of $70^{\circ} \mathrm{N}$ within the three

329 day period of leaving Iceland. With the same simulation start height $(100 \mathrm{~m})$ for

330 both the full and dust-associated trajectories, one clear feature is the greatly

331 reduced density of trajectories over Greenland for the dust-associated air

332 parcels.

334 To examine the potential for variability in pathway characteristics with altitude,

335 the dust-associated trajectories were compared for two different starting

336 heights of $100 \mathrm{~m}$ and $500 \mathrm{~m}$ a.g.I. (Figure 3). Simulations from Grímsstaðir

337 starting at $100 \mathrm{~m}$ showed that the vast majority of trajectories do not rise

338 vertically and remain under $500 \mathrm{~m}$ (Figure 3A, 3C). For this low level start

339 height, the density maps indicate that both the northerly and westerly

340 pathways for dust from northern Iceland are best developed by trajectories

341 occurring <100 m; westerly trajectories reach the coast of Greenland (Figure

$3423 \mathrm{~A}, 3 \mathrm{C})$

$343>>$ Figure $3<<$

344 Results from simulations started at both $100 \mathrm{~m}$ and $500 \mathrm{~m}$ show that

345 trajectories must exceed $500 \mathrm{~m}$ altitude to pass over Greenland, and are more 
346 likely to do so if the trajectories originate at $500 \mathrm{~m}$ (Figure 3E, 3F). For those

347 dust-associated trajectories initiated at $500 \mathrm{~m}$ and reaching $>1500 \mathrm{~m}$, just

348 over a quarter cross Greenland (Figure $3 \mathrm{H}$ ), although this represents only

$3492.5 \%$ of the total trajectory points started at $500 \mathrm{~m}$. Relatively few of the

350 trajectories starting at $500 \mathrm{~m}$ descend to $<100 \mathrm{~m}$ (Figure 3B).

352 The spatial characteristics of dust-related air parcels with height originating at

353 Grímsstaðir contrast with those from Vatnsskarðshólar (Figure 4). At the 100

$354 \mathrm{~m}$ start height, the southerly pathway from Vatnsskarðshólar extends to $55^{\circ} \mathrm{N}$

355 for trajectory points $<100 \mathrm{~m}$ (Figure 4A), while both the southerly and

356 southwesterly pathways are best defined by air parcels between 100 and 500

$357 \mathrm{~m}$ (Figure 4C). The simulations begun at $500 \mathrm{~m}$ from Vatnsskarðshólar

358 indicate that the southerly Icelandic dust pathway is most active for lower level

359 trajectories between 100-500 m (Figure 4D). The passage of dust to the

360 southwest is more associated with trajectories at higher altitudes (500-1500

$361 \mathrm{~m})$ (Figure 4F). Very few air parcels climb to above $1500 \mathrm{~m}$ from

362 Vatnsskarðshólar (Figure 4G, 4H).

$363>>$ Figure $4<<$

364 Another important potential driver of dust pathways is seasonality (e.g.,

365 McGowan and Clark, 2008). The seasonal spatial distribution of trajectory

366 lines computed from $100 \mathrm{~m}$ a.g.I. when dust was observed at Grímsstaðir is

367 shown in Figure 5. A clear feature of the winter (December-February) period

368 for the Grímsstaðir station is that dust activity is infrequent, with very few dust 
May) has more activity, with the most common routes for dust at this time

371 being to the northeast. The majority of trajectories $(58.6 \%)$ from the north of

372 Iceland occur in summer (June-August). The likelihood of dust being

373 transported to the south over the North Atlantic is greatest in these JJA

374 months, and overall trajectory dispersal is also most widespread in this period,

375 including the greatest potential to reach Greenland. In the autumn period

376 (September-November), fewer trajectories head to the south and the northerly

377 pathway becomes more dominant.

$378>>$ Figure $5<<$

379 For dust observed at Vatnsskarðshólar, winter again emerges as the least

380 active period, but for this site, the percentage of trajectories occurring in

381 winter is around six times greater than at Grímsstaðir (9.4\%) (Figure 6). In

382 MAM $35.4 \%$ of trajectories occur, and in JJA 33.4\%, indicating a similar

383 degree of activity for both of these seasons. In MAM however, the pathway to

384 the southwest of Iceland appears to be more prevalent, whereas the

385 frequency of dust transport to the south or southeast increases during JJA.

386 The southerly dust route is also dominant in autumn.

$387>>$ Figure $6<<$

5. Discussion

390 The first output of this study was a comparison between all possible air parcel

391 trajectories and those trajectories constrained to occasions of dust

392 observation at meteorological stations in north and south Iceland (Figure 2).

393 From the 20 year dataset, the modelled transport patterns indicate there are 
considerable differences between a gross assessment based on all pathways versus those that are specifically dust-associated. An important note in this case is that such differences may be especially pronounced in the case of high-latitude dust source regions. In high-latitude environments, acute temporal variability of sediment availability has been identified as a critical factor in controlling dust activity (e.g., Nickling, 1978; Bullard et al., 2016). The clearest example of this is the dust pathway behaviour in winter from the northern site of Grímsstaðir. Here, emission and therefore transport is effectively shut down by winter snow cover in northern Iceland (Figure 5) (Dagsson-Waldhauserova et al., 2013). The trajectory distribution from Grímsstaðir derived from daily-resolved simulations that include the winter period will therefore be heavily biased by trajectories unlikely to be dust laden (Figure 2A). Furthermore, in a daily climatology not discerned by dust, trajectories on days where windspeed is below the threshold for entrainment will also be included. It is by linking trajectories to the presence of dust that the preferential pathways for dust transport from Iceland emerge (Figure 2B and 2D).

The long term analysis of trajectories associated with observed dust days from Iceland reveals particular patterns, but before any inferences can be made about the pathways from specific source areas, the spatial relationship between each dust observing station and the major emission sources needs to be considered. For example, Dagsson-Waldhauserova et al. (2013) have demonstrated that the major source area for dust events recorded at Grímsstaðir is the sandy glacial floodplain of Dyngjusandur which lies to the 
419 south of Grímsstaðir (Figure 1). The relative position of the source and the

420 meteorological station means that episodes of above-threshold winds from the

421 north that are capable of entraining dust from Dyngjusandur and transporting

422 it to the south are unlikely to be detected at Grímsstaðir. As a result of this

423 spatial relationship, there is a likelihood that computation of trajectories for

424 dust observed at Grímsstaðir will not represent all instances that the

425 Dyngjusandur source was emitting. Analysis of the long term wind

426 characteristics at Grímsstaðir however reveals that the majority of winds likely

427 to be competent for dust entrainment $\left(>8 \mathrm{~ms}^{-1}\right)$ (Gisladottir et al., 2005) are

428 south-southwesterly (Figure 7). This indicates that Grímsstaðir is located

429 downwind of the major source area for the majority of potentially dust raising

430 occasions, and therefore represents an appropriate monitoring station from

431 which to make inferences about the fate of dust from the Dyngjusandur

432 source.

$433<<$ Figure $7>>$

434 Seasonal wind roses for Vatnsskarðshólar reveal the dominance of strong

435 surface winds from an easterly direction (Figure 8). This wind regime and the 436 upwind location of Mýrdalssandur and Skeiðararsandur as source surfaces to 437 the east and north-east of Vatnsskarðshólar suggests that this station is likely 438 to record the majority of local dust events (Figure 1). Westerly winds are rare

439 for Iceland (Einarsson, 1984), but a component of this at Vatnsskarðshólar 440 during summertime effectively links dust observations in JJA to possible 441 emission from the coastal Landeyjarsandur source (Figure 1, Figure 8). The 442 differences in the wind roses between the two stations partly demonstrate the 443 importance of local, topographic influence on near-surface airflow at 
444 Vatnsskarðshólar and reduced topographic influence on airflow at the more

445 open location of Grímsstaðir (Dagsson-Waldhauserova et al., 2013).

$446<<$ Figure 8>>

447 With an understanding of the relationship between observed dust days at

448 Grímsstaðir and Vatnsskarðshólar and the specific Icelandic dust sources that

449 these stations may be taken to reflect, the drivers of the large-scale transport

450 pathways can be interpreted. The key dust transport pathways from Iceland

451 relate chiefly to major wind systems associated with the large scale synoptic

452 circulation for the North Atlantic and sub-Arctic region. Wind patterns over

453 Iceland are strongly controlled by the presence of the Icelandic Low, a

454 persistent low pressure feature lying to the southwest of the country which

455 establishes the most common flow over Iceland as from between northeast

456 and south (Einarsson, 1984; Arnalds et al., 2016). In this region, individual

457 cyclonic systems frequently occur as disturbances from the polar front, and

458 movement of these systems west to east in the vicinity of Iceland can cause

459 large surface pressure variations, which have been studied in detail by

460 Serreze et al. (1997) and Nawri (2015). The typical high wind speed events

461 resulting from this can account for the average dust pathway patterns seen

462 from both Grímsstaðir and Vatnsskarðshólar.

463

464 Figures $2 \mathrm{~B}$ and $2 \mathrm{D}$ reveal that a broad pathway to the west-southwest of

465 Iceland toward Greenland and into the Denmark Strait is common to both

466 Grímsstaðir and Vatnsskarðshólar. This route for dust is attributable to the

467 influence of easterly winds associated with the dominant track for cyclonic 
passage that exists to the south of Iceland (Olafsson et al., 2007;

469 Thorsteinsson et al., 2011; Arnalds et al., 2016). Activation of this pathway

470 occurs when the pressure fields during cyclonic events are sufficient to

471 generate dust-raising winds and when the surface is susceptible to erosion.

472 Thus, the dust pathway to the west of Iceland is most apparent during the

473 summer for Grímsstaðir and spring for Vatnsskarðshólar (Figures 5B and 6C),

474 with the later occurrence at the more northerly Grímsstađir where snow cover

475 is more prolonged (Dagsson-Waldhauserova et al., 2013). The contribution of

476 this pathway to the west-southwest, well defined in the trajectory analysis,

477 was not considered by Arnalds et al. (2014) in their first attempt to estimate

478 the loading of Icelandic dust to surrounding marine systems.

480 From Grímsstaðir, another preferential route for dust can be seen heading to

481 the north-northeast (Figure 2B, Figure 5). This path is associated with strong

482 southerly (SW-S-SE) winds that are typical in the northern part of Iceland,

483 driven by winds at the western or leading edge of anticlockwise cyclonic

484 systems as they pass west to east below Iceland (Einarsson, 1984; Dagsson-

485 Waldhauserova et al., 2013; Arnalds et al., 2014). Throughout the year, the

486 most common threshold-exceeding surface winds are from the south (Figure

487 7), and while the strongest winds are most frequent in winter, snow cover

488 makes this a time of reduced dust emission in northern Iceland (Figure 5A)

489 (Dagsson-Waldhauserova et al., 2013). While Dagsson-Waldhauserova et al.

490 (2013) report that springtime dust events in northeastern Iceland are

491 commonly associated with near surface winds from the southeast, the

492 trajectory analysis from a $100 \mathrm{~m}$ start height reveals the dominant long 
distance transport pathway from Grímsstaðir is to the northeast in MAM

494 (Figure 5B). This indicates that while surface wind conditions at source drive entrainment activity, they are not necessarily the best indicator of long range

496 transport patterns.

498 For Vatnsskarðshólar, the majority of the strongest surface winds occur from 499 the east (Figure 8), establishing a route for dust from southern sandar sources 500 that has been noted to affect Reykjavík (Thorsteinsson et al., 2011). In the 501 current study, $6.25 \%$ of all dust-associated trajectories run forward from 502 Vatnsskarðshólar were found to track over or within $25 \mathrm{~km}$ of the municipality 503 area of Reykjavik. The occurrence of relatively infrequent westerly flows (most 504 common in summer, Figure 8) is related to cyclones taking a less usual, more 505 northerly course between Greenland and Iceland (Arnalds et al., 2016). While 506 most near-surface winds occur from the east, air parcel trajectories originating 507 at $100 \mathrm{~m}$ reveal that a well-defined path for dust from Vatnsskarðshólar 508 advects southward, indicating a distinct route into the mid-Atlantic (Figure 2D,

509 Figure 6). This pathway has been illustrated in MODIS imagery of dust storms 510 by Prospero et al. (2012) and Arnalds et al. (2014) in their approach of 511 estimating dust deposition rates into marine regions surrounding Iceland. 512 Arnalds et al. (2014) discuss dry northeasterly winds as the main driver of 513 dust transport from the southern coastal sandurs to the south, which are often 514 brought about by conditions of high pressure over Greenland, and deep 515 cyclonic systems east of Iceland (Einarsson, 1984; Blechschmidt et al., 2012). 516 The southerly pathway from Vatnsskarðshólar to the North Atlantic is evident 517 all year round, but is most active in JJA, and is the dominant pathway in SON 
518

519

524 Trajectory analysis suggests that dust originating from both northern and

when it is more active than the broad west-southwesterly path to Greenland (Figure 6). The prominence of this pathway was in fact demonstrated in real time aerosol trace monitoring by Ovadnevaite et al. (2009) who linked aerosol sampling conducted on the west coast of Ireland, to an individual long distance $(1300 \mathrm{~km})$ Icelandic summertime dust event. southern sources has the potential to impact the North Atlantic Ocean (Figure 5C, 6). For Vatnsskarðshólar, the occurrence and extent of trajectories into the North Atlantic is roughly equal between spring and summer (Figure 6B, 6C), but contributions from Grímsstaðir primarily occur in the summer. In contrast, dust contributions to the Greenland Sea and Norwegian Sea is almost exclusively from sources in the north of Iceland (Figure 5). This is likely to be because northerly winds above threshold on the south coast are rare (Figure 8) and because winds to the south are promoted by both orographic and glacial influences immediately to the north of the southern coastal sources (Einarsson, 1984) (Figure 1).

While the cyclonic systems that bring about strong northerly and southerly flows are frontal and often precipitation bearing, Arnalds et al. (2016) comment that the altitudinal barriers imposed by highlands and glaciated parts of Iceland can create leeward rain shadow regions that are significant for dust-raising potential. The same study demonstrates that precipitation in northern Iceland is rare during southerly winds, and rare in southern Iceland 
542 for northerly winds. These rain shadow conditions on the opposite sides of

543 barriers help explain the transport route to the south from Vatnsskarðshólar

544 (Figure 2D) under northerly winds, and the northern pathway from Grímsstaðir

545 (Figure 2B) during southerly winds.

547 Analysis of the trajectories by height shows the relative lack of vertical

548 development for air parcels from both Grímsstaðir and Vatnsskarðshólar

549 (Figure 3 and 4). This may be attributable to the dominance of stable

550 atmospheric conditions throughout the region which prevents trajectories from

551 achieving higher altitudes within the three day simulation (Harris et al., 2005).

552 Arnalds et al. (2014) in their calculation of the Icelandic dust sediment budget

553 also commented that dust storms in the region are typically associated with

554 conditions of stable, stratified flow. They point out that air masses only have a

555 short duration of advection over land from the central Icelandic dust source

556 area of Dyngjusandur before reaching the coast, and therefore receive

557 relatively limited warming from the surface, even in summer months. Any

558 thermal influence is even more limited for dust emitted from sandar on the

559 southern coast (Figures 1 and 4). This is in contrast to the dynamics of desert

560 dust sources in lower latitudes where convection from strong surface heating

561 encourages rising air parcels and transport of dust at well developed height,

562 for example $>3 \mathrm{~km}$ for the Saharan dust pathway over the central Atlantic (Liu

563 et al., 2007). 
565 While analysis of trajectory height is dependent on the reliability of the vertical

566 motion in the HYSPLIT model, some confidence in the findings here stems

567 from the sensitivity analysis of trajectory modelling conducted by Harris et al.

568 (2005). Their study compared the performance of HYSPLIT with NCAR/NCEP

569 reanalysis input data versus other input meteorology, vertical transport

570 methods and different models for trajectories in the Canadian Arctic, thereby

571 considering a similar atmospheric environment to the present study. While not

572 seeking to assess the absolute accuracy of trajectory heights, Harris et al.

573 (2006) found that mean trajectory altitude after 96 hours from NCAR/NCEP

574 reanalysis was within $50 \mathrm{~m}$ of that from alternative ERA-40 input data.

575 Furthermore, their comparison of an isentropic method to estimate vertical

576 motion found that mean trajectory height was $600 \mathrm{~m}$ less than a kinematic

577 calculation of vertical motion. This suggests that in using the latter method for

578 the current Icelandic study, our approach is not under-estimating trajectory

579 height, strengthening the suggestion that trajectories and dust transport

580 remains relatively low level.

581

582 The systematic trajectory analysis presented here reveals that most air

583 parcels starting from $500 \mathrm{~m}$ or less from Iceland have little potential to cross

584 onto the Greenland Ice Sheet (GrIS). The fact that trajectories are seen to

585 skirt the edge of the GrIS indicates that three day simulations provide

586 adequate time for air parcels to reach the Greenland coast, but that the lack of

587 vertical motion restricts parcels from ascending onto the ice (e.g., Figure 3A,

588 3D). The steep terrain at the edge of Greenland exerts an influence that

589 prevents low-level trajectories cross onto land, and the trajectory point density 
590

in Figure 3 reveals that air parcels starting at 500 m from Grímsstaðir

591 represent the most likely route for dust to Greenland, but only $5.3 \%$ of total

592 trajectory points are found to reach over Greenland. For trajectories run from

593 Grímsstaðir at the extreme start height of 2000 m (not shown here), the

594 proportion marginally increases to $6.5 \%$ indicating that start height does not

595 dramatically influence the potential for Icelandic dust to reach the GrIS. A

596 number of regions have been identified as contributing dust to the GrIS

597 including both distal sources in North Africa and Asia, and high-latitude dust

598 sources (Kahl et al. 1997; VanCuren et al., 2012). Groot-Zwaaftink et al.

599 (2016) modelled dust deposition in the Arctic and concluded that the relative

600 importance of different sources depends on the altitude of the surface on

601 which the dust is being deposited. For example, over Greenland in total $67 \%$

602 of dust is of high-latitude origin, but over the highest parts of the GrIS this

603 contribution drops to $<15 \%$ because dust transported from Africa and Asia

604 becomes relatively more important. Dust reaching Greenland from Asian and

605 Saharan sources travels thousands of kilometres and will have been

606 thoroughly mixed to high altitudes (e.g., Saharan Air Layer) (Liu et al., 2008;

607 Engelstaedter et al., 2009) enabling the far-travelled dust to penetrate over

608 the GrIS. A mechanism for this high altitude dust being detectable by ground

609 level sampling is the periodic lessening of the semi-permanent temperature

610 inversion over the GrIS at springtime polar sunrise (Mosher et al., 1993).

612 Of the high-latitude dust deposited over the GrIS, a proportion is likely to have

613 originated in Iceland and travelled along the pathways identified in this study.

614 This is also suggested by Drab et al. (2002) who found the presence of glassy 
615 particles up to $5 \mu \mathrm{m}$ diameter in aerosol sampling at Summit, Greenland.

616 They inferred a relatively nearby volcanic source, possibly Iceland, based on

617 the large particle size and composition. While comprising a minority of the

618 material detected (cf. clays), it was suggested these glassy particles might

619 represent volcanic material re-suspended from the surface (e.g.,

620 Thorsteinsson et al., 2012), thus supporting a route from ground level in

621 Iceland to the Greenland Interior. Arrival of Icelandic dust to Greenland has

622 also been suggested by Dagsson-Waldhauserova et al. (2013) based on

623 speculative matching between their meteorological time series of dust

624 observation and the GISP2 ice core dust record presented by Donarummo et 625 al. (2002).

626

627 While the trajectory analysis does not take into account the potential for

628 vertical mixing as a possible means for dust to ingress further onto the GrIS,

629 and it is difficult to verify the accuracy of vertical motion in the HYSPLIT model

630 (Harris et al., 2005), overall, the modelled pathways and regional atmospheric

631 stability suggests that under contemporary wind conditions, dust from Iceland

632 might have a relatively limited potential for cryospheric interactions over GrIS.

633 In terms of cryospheric processes, Icelandic dust sources may be important

634 for local ice caps and glaciers but this has yet to be explored in detail (Casey

635 and Kääb, 2012; Bullard et al., 2016).

\section{Conclusion}


638 This work presents the first long term assessment, constrained by actual dust

639 observations, of dust transport from a high-latitude dust region. Air parcel

640 trajectories were examined for a 20 year period from two source areas

641 exhibiting different emission dynamics due to their location in the north and

642 south of Iceland. By comparing the trajectories of a coarse climatology versus

643 specifically dust-associated trajectories, this study highlights the imperative of

644 basing trajectory analysis for dust transport studies on occasions when dust

645 emission occurred. Studies that use daily-run climatologies at best represent

646 potential pathways and may suggest considerably different transport patterns

647 to those when the analysis is restricted to days when dust activity was

648 observed.

650 A notable aspect of the current study is the fact it was facilitated by the robust

651 sources of meteorological data available for Iceland. Datasets indicating the

652 presence and absence of dust are critical to the validity of the approach used,

653 and yet, such meteorological records are sparse in remote high-latitude areas.

654 Exploring the availability of datasets in other high-latitudes is key to a wider,

655 global assessment of dust transport from these regions. Weather

656 observations from meteorological stations offer a useful indicator for the

657 presence of dust, but as this paper has discussed, station position in relation

658 to source areas, and the influence of prevailing wind direction, means

659 meteorological stations can only be considered proxies for sources of

660 emission. The spatial disconnect between meteorological sites and source

661 areas, and the variability of wind fields, means there is always a potential for

662 emission to be missed when analysis is led by meteorological observations. 
664 In terms of the Icelandic dust system, the analysis has defined preferential 665 pathways that demonstrate the role of Iceland in distributing dust to the 666 Northern Atlantic and sub-arctic oceans. Apparent for dust emitted from both 667 the southern coastal and northeast sandur (glacial outwash floodplain) 668 sources is a pathway of dust to the west-southwest of Iceland into the 669 Denmark Strait and towards Greenland. From northern sources, a route also 670 exists to the northeast, into the Norwegian, Greenland and Barents Seas, 671 although there is also potential for delivery to the North Atlantic Ocean in 672 summer months. From the southern sources, the dominant pathway extends 673 into the North Atlantic, with elevated trajectory frequency extending as far as $67450^{\circ} \mathrm{N}$, particularly in spring and summer. For simulations run from $<500 \mathrm{~m}$, 675 where concentrations of dust are greater in the lower atmospheric boundary 676 layer, trajectories reveal that the vertical development of dust plumes from 677 Iceland is limited. This is likely due to the stable air masses of the region 678 suppressing the potential for vertical motion of air parcels and therefore 679 transport of mineral aerosol. Such an influence on airflow has implications for 680 the likelihood of dust reaching the major cryospheric system of the Greenland 681 Ice Sheet, with trajectories being unlikely to ascend high enough to reach the 682 central ice sheet. From an Earth systems view, the overall distribution of 683 trajectories indicates that contributions of Icelandic dust are relatively more 684 important for neighbouring marine environments.

\section{Acknowledgements}


687 This research was part-funded by a Leverhulme Trust International Network 688 grant (IN-2013-036). The authors gratefully acknowledge the NOAA Air 689 Resources Laboratory (ARL) for provision of the HYSPLIT transport model 690 (http://www.ready.noaa.gov/), and data made freely available by the Icelandic 691 Meteorological Office. Cartography was produced by Mark Szegner. We thank 692 Roland Draxler and Ariel Stein for personal communications, and are also 693 grateful to two anonymous reviewers and the editor whose comments 694 improved the manuscript. 695 
696 Table 1: Details of study meteorological stations and 1992-2012 dust 697 observation datasets

\begin{tabular}{|c|c|c|c|c|}
\hline & Location & Altitude $(\mathrm{m})$ & $\begin{array}{l}\text { Number of } \\
\text { dust days }\end{array}$ & $\begin{array}{l}\text { Average } \\
\text { dust days } \\
\text { per year }\end{array}$ \\
\hline Grímsstaðir & $\begin{array}{c}16.121^{\circ} \mathrm{W} \\
65.642^{\circ} \mathrm{N}\end{array}$ & 384 & 202 & 10.1 \\
\hline Vatnsskarðshólar & $\begin{array}{c}19.183^{\circ} \mathrm{W} \\
63.424^{\circ} \mathrm{N}\end{array}$ & 20 & 160 & 8 \\
& & & & \\
\hline
\end{tabular}

698

699 


\section{Figure Captions}

701 Figure 1: A) Regional map with key locations for the study. Area of active

702 aeolian surfaces is based on the two highest wind erosion severity land

703 classification categories from Arnalds et al. (2016). B) Landsat Thematic

704 Mapper mosaic of Iceland showing land surfaces. Data from the USGS Tri-

705 Decadal Global Landsat Orthorectified Overview.

706

707 Figure 2: Trajectory line density (\% of trajectories per $1^{\circ} \times 1^{\circ}$ cell) for 72 hour 708 simulations run at a $100 \mathrm{~m}$ start height from Grímsstaðir for all days 19927092012 (A), and dust observation days only (B), from Vatnsskarðshólar for all 710 days 1992-2012 (C), and dust observation days only (D). See Figure 1 for 711 trajectory start points.

713 Figure 3: Trajectory point density ( $\%$ of points per $1^{\circ} \times 1^{\circ}$ cell) at different 714 altitudes for 72 hour simulations started at $100 \mathrm{~m}$ height (left hand column) 715 and $500 \mathrm{~m}$ height (right hand column), originating from Grímsstaðir for days of 716 observed dust 1992-2012. See Figure 1 for trajectory start points.

717

718 Figure 4: Trajectory point density ( $\%$ of points per $1^{\circ} \times 1^{\circ}$ cell) at different 719 altitudes for 72 hour simulations started at $100 \mathrm{~m}$ height (left hand column) 720 and $500 \mathrm{~m}$ height (right hand column), originating from Vatnsskarðshólar for 721 days of observed dust 1992-2012. See Figure 1 for trajectory start points.

723 Figure 5: Seasonal variation in trajectory line density (\% of trajectories per $7241^{\circ} \times 1^{\circ}$ cell) for simulations started at $100 \mathrm{~m}$ height originating from Grímsstaðir 725 on days of observed dust 1992-2012. See Figure 1 for trajectory start points.

727 Figure 6: Seasonal variation in trajectory line density (\% of trajectories per $1^{\circ} \times 1^{\circ} \mathrm{cell}$ ) for simulations started at $100 \mathrm{~m}$ height originating from 
729 Vatnsskarðshólar on days of observed dust 1992-2012. See Figure 1 for 730 trajectory start points.

731

732 Figure 7: Directional frequency of winds $\left(>8 \mathrm{~m} \mathrm{~s}^{-1}\right)$ representing near-surface

733 airflow at Grímsstaðir, as derived from mean three-hourly wind speeds for the 734 whole study period 1992-2012.

735

736 Figure 8: Directional frequency of winds $\left(>8 \mathrm{~m} \mathrm{~s}^{-1}\right)$ representing near-surface 737 airflow at Vatnsskarðshólar, as derived from mean three-hourly wind speeds 738 for the whole study period 1992-2012.

739 
741 Arnalds, O. (2010), Dust sources and deposition of aeolian materials in

742 Iceland, Icelandic Agricultural Sciences, 23, 3-21.

743

744 Arnalds, O., F. O. Gisladottir, and H. Sigurjonsson (2001), Sandy deserts of

745 Iceland: an overview, J. Arid. Environ., 47(3), 359-371,

746 doi:10.1006/jare.2000.0680.

747

748 Arnalds, O., H. Olafsson, and P. Dagsson-Waldhauserova (2014),

749 Quantification of iron-rich volcanogenic dust emissions and deposition over

750 the ocean from Icelandic dust sources, Biogeosciences, 11, 6623-6632,

751 doi:10.5194/bg-11-6623-2014.

752

753 Arnalds, O., P. Dagsson-Waldhauserova, and H. Olafsson (2016), The

754 Icelandic volcanic aeolian environment: Processes and impacts - A Review.

755 Aeolian Res., 20, 176-195. doi: 10.1016/j.aeolia.2016.01.004

756

757 Atkins, C. B., and G. B. Dunbar (2009), Aeolian sediment flux from sea ice

758 into southern McMurdo Sound, Antarctica, Global Planet. Change, 69, 133-

759 141, doi:10.1016/j.gloplacha.2009.04.006.

760

761 Bhattachan A., D’Odorico P., Baddock M., Zobeck T., Okin G. and Cassar N.

762 (2012) The Southern Kalahari: A potential new dust source in the southern 
763 hemisphere? Environ. Res. Lett., 7: 024001. doi: 10.1088/1748-

$7649326 / 7 / 2 / 024001$

765

766 Bhattachan, A., L. Wang, M. F. Miller, K. J. Licht, and P. D'Odorico (2015),

767 Antarctica's Dry Valleys: A potential source of soluble iron to the Southern

768 Ocean? Geophys. Res. Lett.,42(6),1912-1918.

769

770 Blechschmidt, A.-M., Kristjansson, J.E., Olafsson, H., Burkhart, J.F.,

771 Hodnebrog, $\varnothing ., 2012$. Aircraft-based observations and high-resolution

772 simulations of an Icelandic dust storm. Atmos. Chem. Phys. 12, 10649-

773 10666. doi:10.5194/acp-12-10649-2012.

774

775 Bullard, J. E (2013), Contemporary glacigenic inputs to the dust cycle, Earth

776 Surf. Proc. Land., 38, 71-89, doi:10.1002/esp.3315.

777

778 Bullard J.E., Baddock M., Bradwell T., Crusius J., Darlington E., Gaiero D.,

779 Gassó S., Gisladottir G., Hodgkins R., McCulloch R., McKenna Neuman C.,

780 Mockford T., Stewart H., and Thorsteinsson T. (2016) High-latitude dust in the

781 Earth system. Rev. Geophys., 54. doi: 10.1002/2016RG000518

782

783 Casey, K., and Kääb, A. (2012), Estimation of supraglacial dust and debris

784 geochemical composition via satellite reflectance and emissivity, Remote

785 Sens., 4, 2554-2575. doi: 10.3390/rs/4092554 
787 Chewings, J. M., C. B. Atkins, G. B. Dunbar, and N. R. Golledge (2014),

788 Aeolian sediment transport and deposition in a modern high-latitude glacial

789 marine environment, Sedimentology, 61(6), 1535-1557,

790 doi:10.1111/sed.12108.

791

792 Crusius, J., A. W. Schroth, S. Gassó, C. M. Moy, R. C. Levy, and M. Gatica

793 (2011), Glacial flour dust storms in the Gulf of Alaska: Hydrologic and

794 meteorological controls and their importance as a source of bioavailable iron,

795 Geophys. Res. Lett., 38, L06602, 10.1029/2010gl046573.

796

797 Dagsson-Waldhauserova, P., O. Arnalds, and H. Olafsson (2013), Long-term

798 frequency and characteristics of dust storm events in Northeast Iceland

799 (1949-2011), Atmos. Environ., 77, 117-127,

800 doi:10.1016/j.atmosenv.2013.04.075.

801

802 Dagsson-Waldhauserova, P., O. Arnalds, and H. Olafsson (2014), Long-term 803 variability of dust events in Iceland (1949-2011), Atmos. Chem. Phys., 14, 804 13411-13422, doi:10.5194/acp-14-13411-2014.

805

806 Donarummo, J., M. Ram, and M.R. Stolz (2002) Sun/dust correlations and

807 volcanic interference, Geophys. Res. Lett., 29(9), 1361,

808 10.1029/2002GL014858. 
810 Drab, E., Gaudichet, A., Jaffrezo, J.L., Colin, J.L., 2002. Mineral particles

811 content in recent snow at Summit (Greenland). Atmos. Environ., 36, 5365-

8125376.

813

814 Draxler, R.R., and G.D. Hess, (1997) Description of the HYSPLIT_4 modeling

815 system. NOAA Tech. Memo. ERL ARL-224, NOAA Air Resources Laboratory,

816 Silver Spring, MD, 24 pp

817

818 Draxler, R. R., and G.D. Hess (1998). An overview of the HYSPLIT_4

819 modelling system for trajectories, dispersion and deposition. Australian

820 Meteorol. Mag., 47(4), 295-308.

821

822 Einarsson, M.A. (1984), Climate of Iceland, in H. van Loon (ed.), World

823 Survey of Climatology: 15: Climates of the Oceans. Elsevier, Amsterdam, pp $824 \quad 673-697$.

825

826 Gassó, S. and A.F. Stein (2007), Does dust from Patagonia reach the sub-

827 Antarctic Atlantic Ocean? Geophys. Res. Lett., 34, L01801,

828 doi:10.1029/2006gl027693.

829

830 Gassó, S., A. Stein, F. Marino, E. Castellano, R. Udisti, and J. Ceratto (2010),

831 A combined observational and modeling approach to study modern dust 
832 transport from the Patagonia desert to East Antarctica, Atmos. Chem. Phys.,

833 10, 8287-8303, doi:10.5194/acp-10-1607 8287-2010.

834

835 Gísladóttir, F. O., O. Arnalds, and G. Gísladóttir (2005), The effect of

836 landscape and retreating glaciers on wind erosion in south Iceland, Land

837 Degrad. Dev., 16, 177-187, doi:10.1002/ldr.645.

838

839 Gísladóttir, G., E. Erlendsson, R. Lal., and J. Bigham (2010), Erosional effects

840 on terrestrial resources over the last millennium in Reykjanes, southwest

841 Iceland, Quaternary Res., 73, 20-32, doi:10.1016/j.yqres.2009.09.007.

842

843 Groot-Zwaaftink, C.D., H.Grythe, H.Skov, and A.Stohl (2016), Substantial

844 contribution of northern high-latitude sources to mineral dust in the Arctic, J.

845 Geophys. Res., doi:10.1002/2016JD025482.

846

847 Harris, J., R.R. Draxler, and S.J. Oltmans (2005), Trajectory model sensitivity

848 to differences in input data and vertical transport method, J. Geophys. Res.,

849 110, D14109, doi: 10.1029/2004JD005750.

850

851 Kahl, J.D.W., D.A. Martinez, H. Kuhns, C.I. Davidson, J.-L. Jaffrezo and J.M.

852 Harris (1997), Air mass trajectories to Summit, Greenalnd: A 44-year

853 climatology and some episodic events, J. Geophys. Res., 102, C12, 26,821-

$85426,875$. 
856 Kalnay, E., et al. (1996) The NCEP/NCAR 40-Year Reanalysis Project, Bull.

857 Amer. Meteor. Soc., 77, 437-471, doi:10.1175/1520-

858 0477(1996)077<0437:TNYRP>2.0.CO;2.

859

860 Liu, Z and 11 others (2008) CALIPSO lidar observations of the optical

861 properties of Saharan dust: A case study of long-range transport, J. Geophys.

862 Res., 113, D07207, doi:10.1029/2007JD008878.

863

864 McGowan H, Clark A. (2008), Identification of dust transport pathways from

865 Lake Eyre, Australia using Hysplit. Atmos. Environ., 42, 6915-6925.

866

867 Middleton, N. J., A. S. Goudie, and G. L. Wells (1986), The frequency and

868 source areas of dust storms, In: W. G. Nickling (ed.), Aeolian Geomorphology, 869 pp. 237-259, Allen and Unwin, Boston.

870

871 Mosher, B.W., Winkler, P., Jaffrezo, J.-L. (1993), Seasonal aerosol chemistry

872 at Dye 3, Greenland, Atmos. Environ., 27A (17/18), 2761-2772.

873

874 Muhs D.R., Prospero J.M., Baddock M.C. and Gill T.E. (2014) Identifying

875 sources of aeolian mineral dust: present and past. In: Stuut J.-B. and

876 Knippertz P. (Eds.), Mineral dust - a key player in the Earth system. Springer.

877 pp. 51-74. doi 10.1007/978-94-017-8978-3_3 
879 Nawri, N. (2015) Cyclones and associated weather patterns over the northern

880 North Atlantic region based on ECMWF reanalyses. Report VI 2015-005,

881 Icelandic Meteorological Office, Reykjavik.

882

883 Neff, P.D., and N.A.N. Bertler (2015), Trajectory modelling of modern dust

884 transport to the Southern Ocean and Antarctica, J. Geophys. Res:

885 Atmospheres, 120(18), 9303-9322, doi:10.1002/2015JD023304.

886

887 Nickling, W.1146 G. (1978), Eolian sediment transport during dust storms:

888 Slims River 1147 Valley, Yukon Territory, Can. J. Earth Sci. 15, 1069-1084.

889

890 Nielsdóttir, M.C., C. M. Moore, R. Sanders, D. J. Hinz, and E. P. Achterberg

891 (2009), Iron limitation of the postbloom phytoplankton communities in the

892 Iceland Basin, Global Biogeochem. Cy., 23(3), doi:10.1029/2008gb003410.

893

894 O'Loingsigh, T., G.H. McTainsh, N.J. Tapper and P. Shinkfield (2010), Lost in

895 Code: a critical analysis of using meteorological data for wind erosion

896 monitoring, Aeolian Res., 2, 49-57. doi:10.1016/j.aeolia.2010.03.002

897

898 Olafsson, H., B. Bruemmer, and M. Furger (2007), The weather and climate

899 of Iceland, Meteorol. Z. 16, 5-8. 
901 Old, G. H., D. M. Lawler, and A. Snorrason (2005), Discharge and suspended 902 sediment dynamics during two jökulhlaups in the Skaftá River, Iceland, Earth 903 Surf. Proc. Land., 30, 1441-1460, doi:10.1002/esp.1216.

904

905 Ovadnevaite, J., Ceburnis, D., Plauskaite-Sukiene, K., Modini, R., Dupuy, 906 R.,Rimselyte, I., Ramonet, R., Kvietkus, K., Ristovksi, Z., Berresheim, H., 907 O'Dowd, C. (2009), Volcanic sulfate and arctic dust plumes over the North 908 Atlantic Ocean, Atmos. Environ., 43, 4968-4974.

909

910 Polissar, A. V., P. K. Hopke, P. Paatero, W. C. Malm, and J. F. Sisler (1998),

911 Atmospheric aerosol over Alaska: 2. Elemental composition and sources, J.

912 Geophys. Res. 103(D15), 19045. doi:10.1029/98jd01212.

913

914 Prospero, J. P., J. E. Bullard, and R. Hodgkins (2012), High-latitude dust over 915 the North Atlantic: inputs from Icelandic proglacial dust storms, Science, 335, 916 1078-1082, doi:10.1126/science.1217447.

918 Schroth, A.W., J. Crusius, E. R. Sholkovitz, and B. C. Bostick (2009), Iron

919 solubility driven by speciation in dust sources to the ocean, Nat. Geosci., 2(5), $920 \quad 337-340$ doi:10.1038/NGEO501.

922 Serrezze, M.C., F. Carse, R.G. Barry and J.C. Rogers (1997), Icelandic low 923 cycle activity: climatological features, linkages with the NAO, and relationships 
924 with recent changes in the Northern Hemisphere circulation, J. Climate 10, 925 453-464.

926

927 Stein, A.F., R. R. Draxler, G. D. Rolph, B. J. B. Stunder, M. D. Cohen, and F.

928 Ngan (2015), NOAA's HYSPLIT atmospheric transport and dispersion

929 modelling system, Bull. Amer. Meteor. Soc., 96, 2059-2077.

930 doi:10.1175/BAMS-D-14-00110.1.

931

932 Stohl, A. (1998), Computation, accuracy and applications of trajectories-A

933 review and bibliography, Atmos. Environ., 32(6), 947-966.

934 doi:10.1016/S1352-2310(97)00457-3.

935

936 Thorsteinsson, T., G. Gísladóttir, J. Bullard, and G. McTainsh (2011), Dust

937 storm contributions to airborne particulate matter in Reykjavík, Iceland,

938 Atmos. Environ., 45, 5924- 5933, doi:10.1016/j.atmosenv.2011.05.023.

939

940 Thorsteinsson, T., Johannsson, T., Stohl, A., Kristiansen, N.I., (2012), High

941 levels of particulate matter in Iceland due to direct ash emissions by the

942 Eyjafjallajökull eruption and resuspension of deposited ash, J. Geophys. Res.

943 117, B00C05. doi:10.1029/2011JB008756.

944

945 VanCuren, R. A., T. Cahill, J. Burkhart, D. Barnes, Y. Zhao, K. Perry, S. Cliff, 946 and J. McConnell (2012), Aerosols and their sources at Summit 
947 Greenland-First results of continuous size- and time-resolved sampling,

948 Atmos. Environ., 52, 82-97, doi:10.1016/j.atmosenv.2011.10.047. 

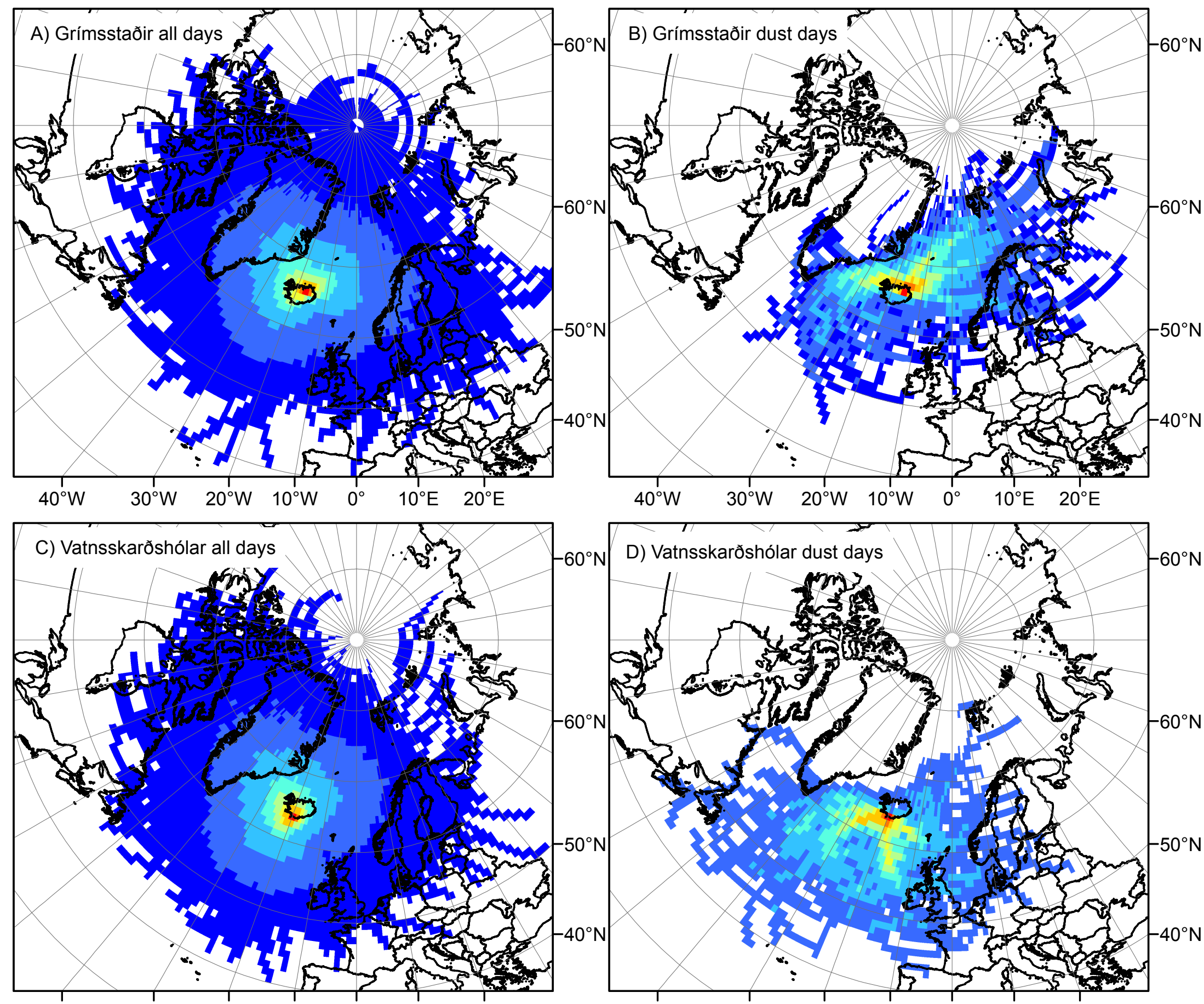

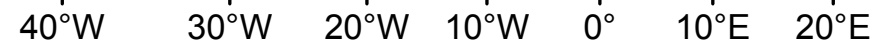

Trajectories (\%)
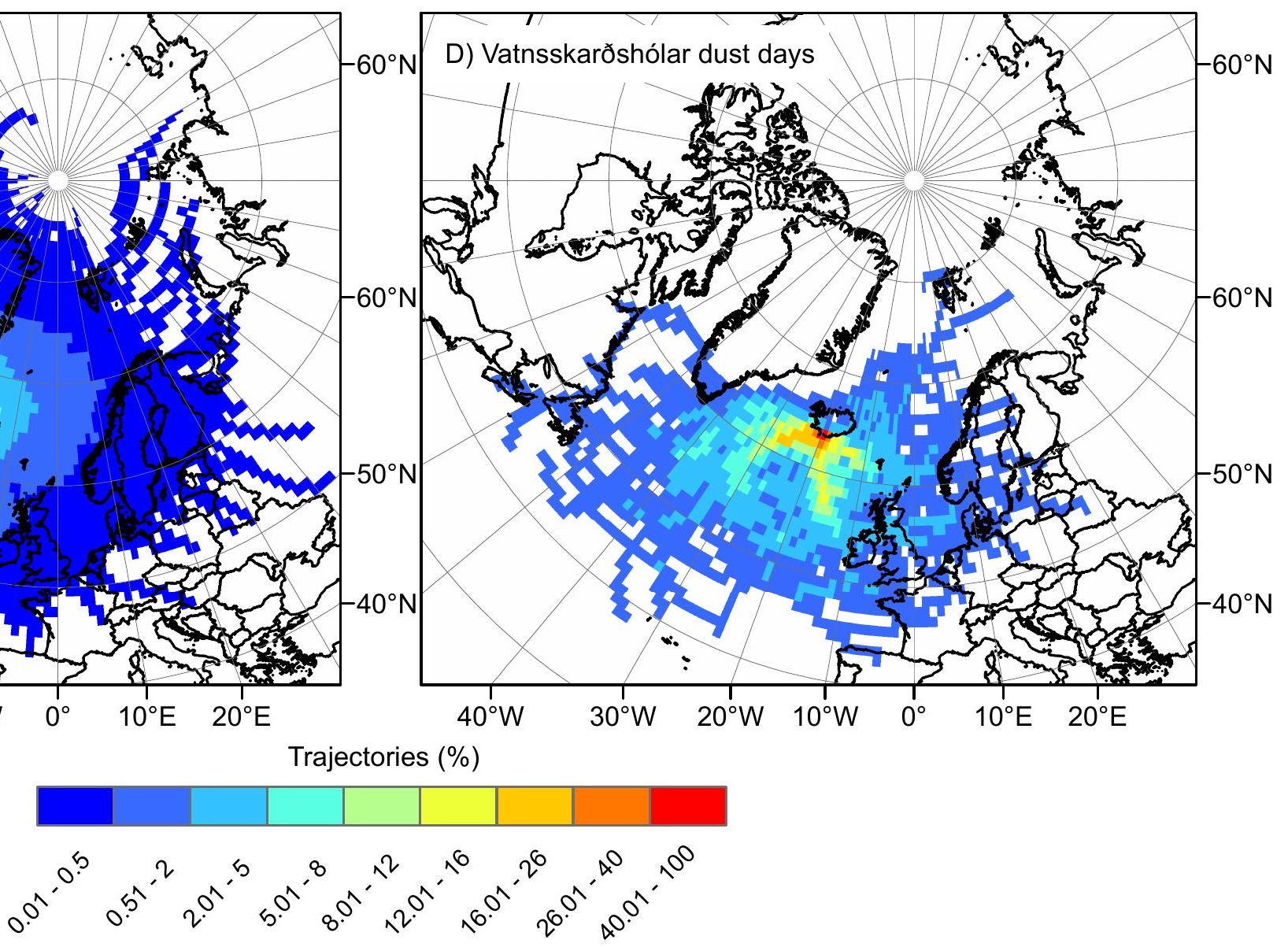

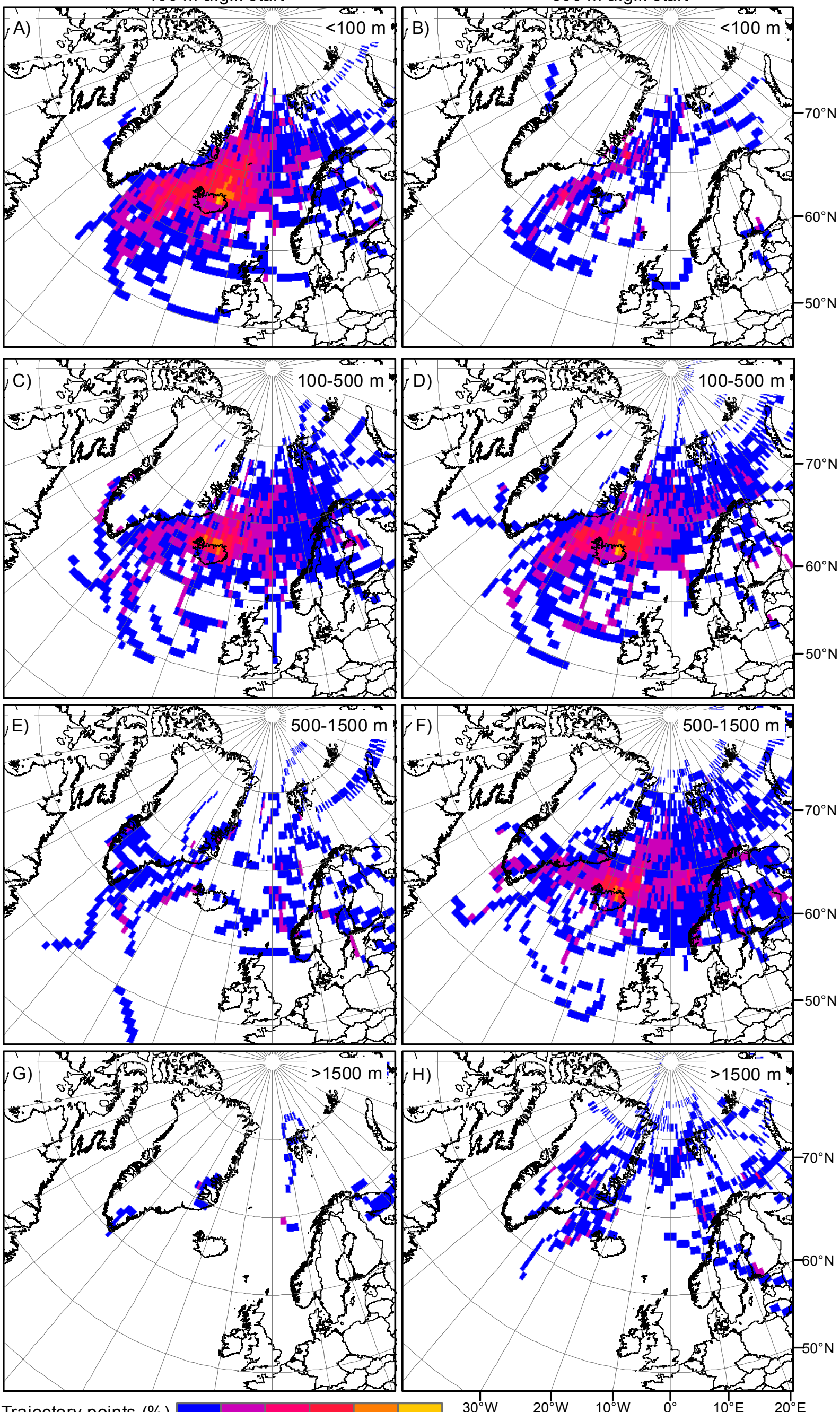

Trajectory points (\%)

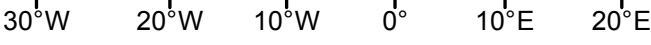



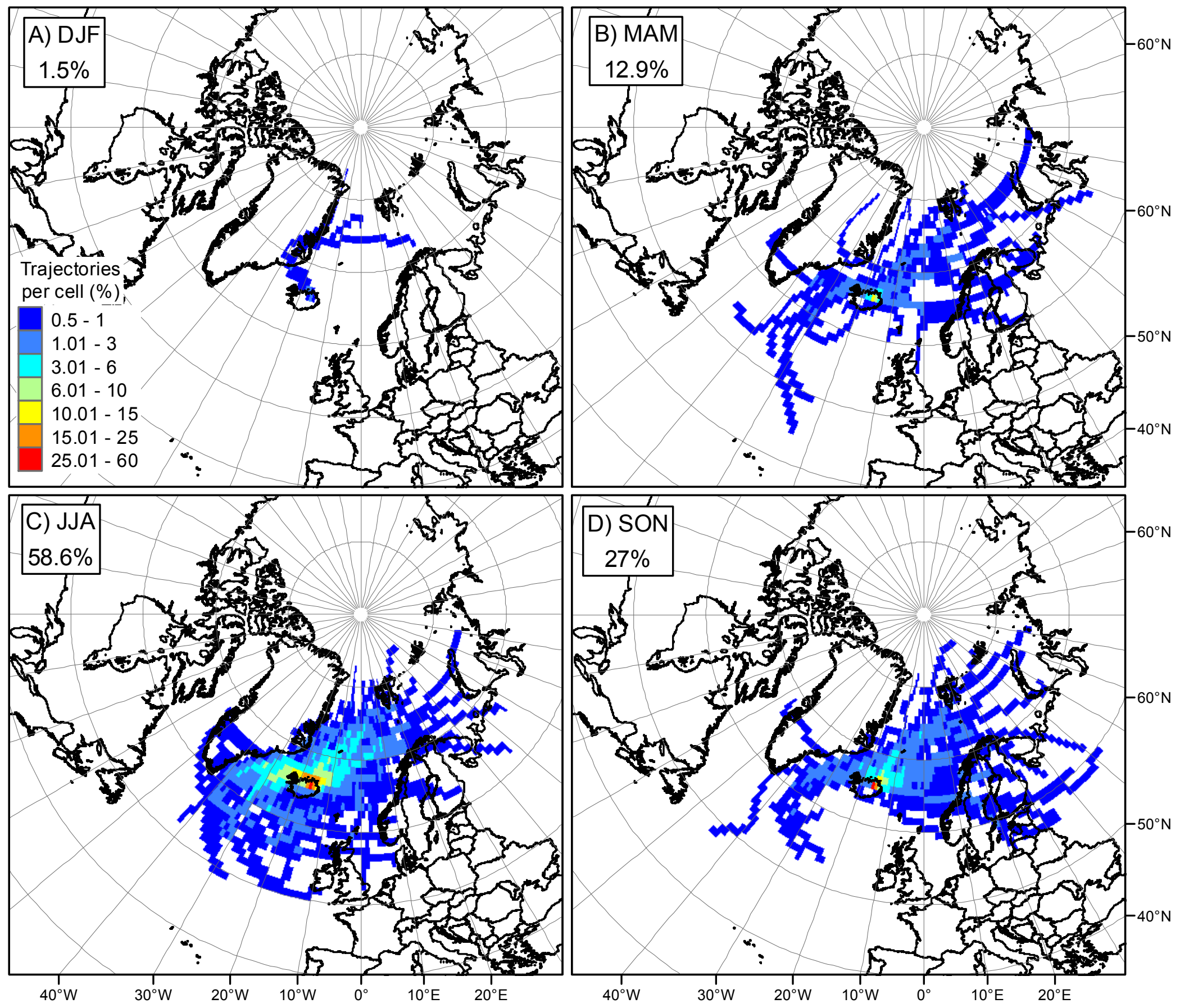

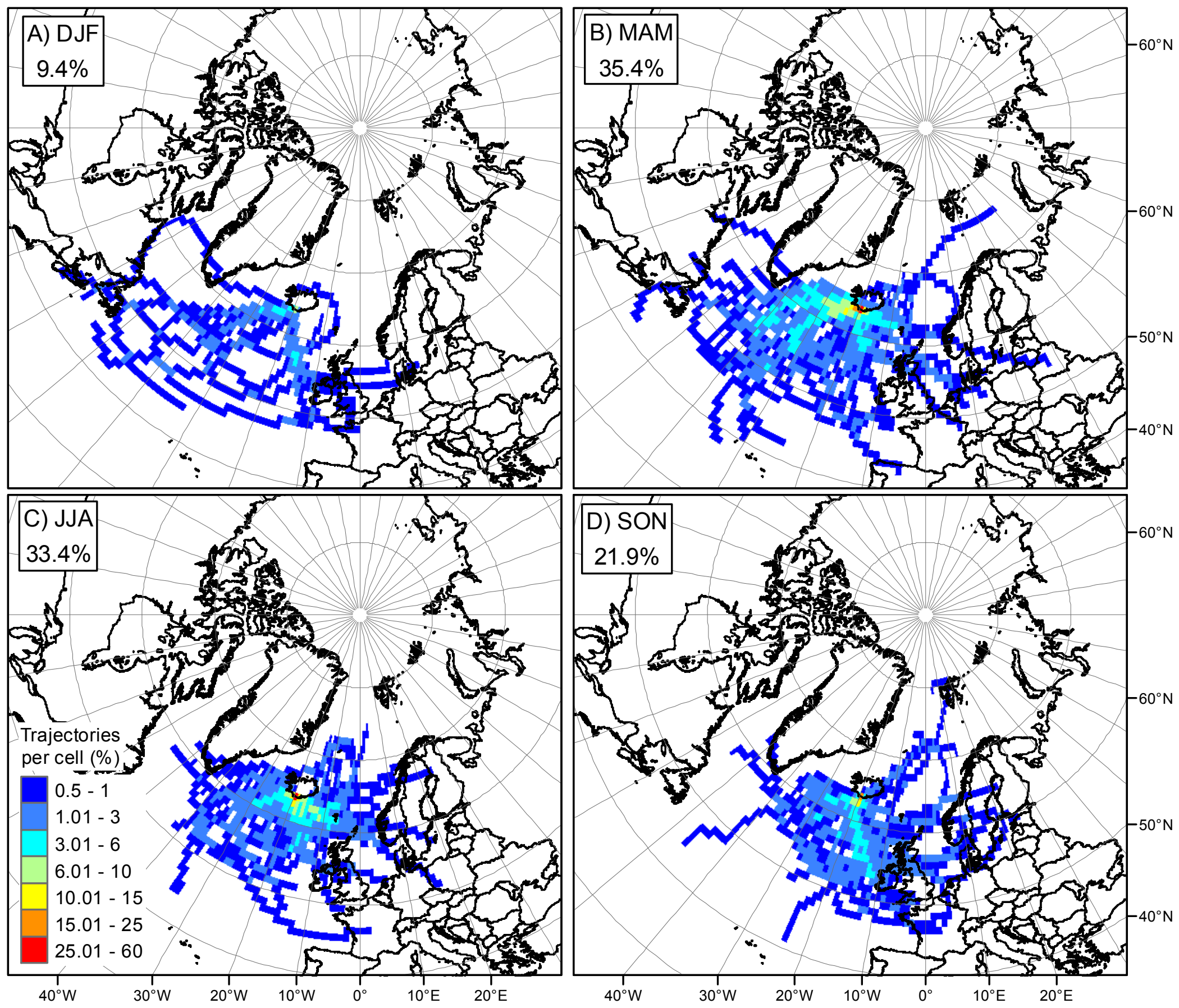

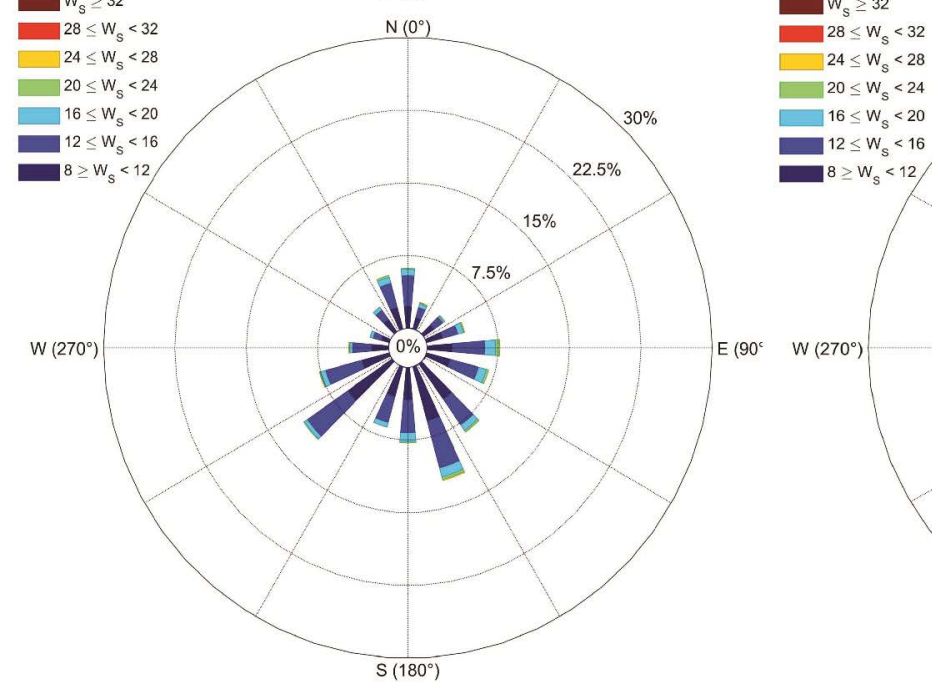

$W\left(270^{\circ}\right)$

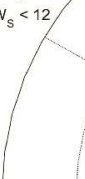

. 


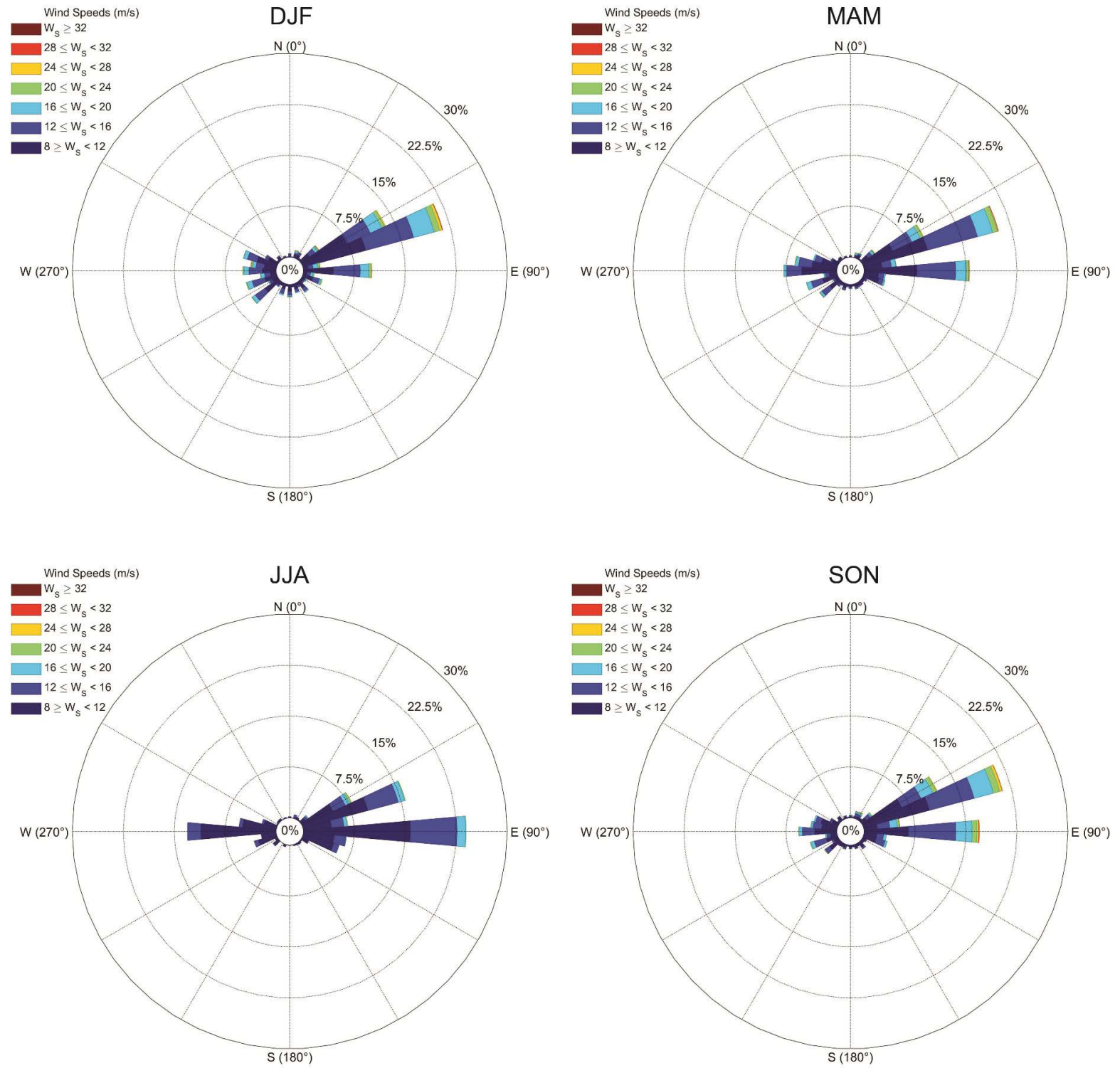

